\title{
Effect of Typha domingensis cutting: response of benthic macroinvertebrates and macrophyte regeneration
}

\author{
Thiago Cesar Lima Silveira ${ }^{1,5}$, Gilberto Gonçalves Rodrigues ${ }^{2}$, \\ Gabriela Peixoto Coelho de Souza ${ }^{3}$ \& Norma Luiza Würdig ${ }^{4}$
}

\author{
${ }^{1}$ Laboratório de Ecologia Aquática, Pontifícia Universidade Católica do Rio Grande do Sul - PUCRS, \\ Av. Ipiranga, 6681, Prédio 12-C, sala 135, Partenon, CEP 90619-900, Porto Alegre, RS, Brazil \\ ${ }^{2}$ Programa de Pós-graduação em Desenvolvimento e Meio Ambiente, Centro de Ciências Biológicas, \\ Universidade Federal de Pernambuco - UFPE, Av. Prof. Moraes Rego, 1235, \\ Cidade Universitária, CEP 50670-420, Recife, PE, Brazil \\ ${ }^{3}$ Programa de Pós-graduação em Desenvolvimento Rural, Centro de Estudos e Pesquisas Econômica, \\ Faculdade de Ciências Econômicas, Universidade Federal do Rio Grande do Sul - UFRGS, \\ Av. João Pessoa, 31, Centro, CEP 90040-000, Porto Alegre, RS, Brazil \\ ${ }^{4}$ Laboratório de Invertebrados Bentônicos, Universidade Federal do Rio Grande do Sul - UFRGS, \\ Av. Bento Gonçalves, 9500, Bairro Agronomia, CEP 91501-970, Porto Alegre, RS, Brazil \\ ${ }^{5}$ Corresponding author: Thiago Cesar Lima Silveira, e-mail: thiagoclsilveira@yahoo.com.br
}

SILVEIRA, T.C.L., RODRIGUES, G.G., COELHO DE SOUZA, G.P. \& WÜRDIG, N.L. Effect of Typha domingensis cutting: response of benthic macroinvertebrates and macrophyte regeneration. Biota Neotrop. 12(3):http://www.biotaneotropica.org.br/v12n3/en/abstract?article+bn03012032012

\begin{abstract}
Wetlands are important because they have high biodiversity and are considered, by environmental agencies, permanently protected areas due to their importance to conservation. In Southern Brazil the aquatic macrophyte Typha domingensis is harvested to be used in the manufacture of handicraft, being an important income source to small farmers. This work aims to test the cut effect of $T$. domingensis on benthic macroinvertebrates as well as on macrophyte regeneration. These phenomena were analyzed in small areas $\left(1 \mathrm{~m}^{2}\right)$ in a T. domingensis stand by comparing cut treatments and control treatments. Macroinvertebrate were sampled with a corer in the following time sequence after the cut event in both treatments: one day, 26 days, 60 days, 89 days, and 182 days. Macrophyte regeneration was monitored through monthly measurements at each treatment. The macroinvertebrate density did not differ between treatments (ANOVA, $\mathrm{p}<0.05$ ). Among the 23 taxa identified, Tubificidae was the only family to response to cut treatment. DCA showed an overlapping between treatments indicating a not clear pattern. The growth of $T$. domingensis shoots was not affected by the disturbance. Macrophyte regeneration was quick when comparing the treatments and statistical differences were found in one day after the disturbance and 26 days after the disturbance, whereas no differences were found in the remaining sampling dates $(60,89$ and 182 days). Observing the macroinvertebrate response and the $T$. domingensis regeneration, our results suggest that sustainable use of this macrophyte is possible on a small scale.
\end{abstract}

Keywords: disturbance, bioindication, vegetal management, aquatic macrophytes, non-wood products.

SILVEIRA, T.C.L., RODRIGUES, G.G., COELHO DE SOUZA, G.P. \& WÜRDIG, N.L. Efeito do corte de Typha domingensis: resposta dos macroinvertebrados bentônicos e a regeneração da macrófita. Biota Neotrop. 12(3):http://www.biotaneotropica.org.br/v12n3/pt/abstract?article+bn03012032012

Resumo: As áreas úmidas são importantes, pois apresentam alta biodiversidade e são consideradas pelos órgãos ambientais áreas de proteção permanente devido à sua importância para conservação. No Sul do Brasil a macrófita aquática Typha domingensis é colhida para ser usada na fabricação de artesanato, sendo uma fonte de renda importante para pequenos agricultores. Este trabalho teve como objetivo testar o efeito de corte de T. domingensis sobre os macroinvertebrados bentônicos, bem como sobre a regeneração da macrófita. Para avaliar o efeito do corte foram analisadas pequenas áreas $\left(1 \mathrm{~m}^{2}\right)$ em uma formação de $T$. domingensis onde comparou-se o tratamento de corte com tratamentos controle. Macroinvertebrados foram amostrados com um "corer" na seguinte sequência de tempo após o corte, em cada tratamento: um dia, 26 dias, 60 dias, 89 dias e 182 dias. A regeneração da macrófita foi monitorada através de medições mensais em cada tratamento. Não houveram diferenças significativas na densidade de macroinvertebrados entre os tratamentos (ANOVA, p < 0.05). Entre os 23 táxons identificados, Tubificidae foi a única família a responder ao tratamento de corte. A DCA mostrou uma sobreposição entre os tratamentos, indicando um padrão não claro. $\mathrm{O}$ crescimento dos ramos de $T$. domingensis não foi afetado pelo distúrbio. A regeneração da macrófita foi rápida quando se compararam os tratamentos, diferenças estatísticas foram encontradas em um dia e 26 dias após o corte, enquanto não foram encontradas diferenças nas datas de amostragem restantes $(60,89$ e 182 dias). Observando a resposta dos macroinvertebrados e a regeneração de T. domingensis, sugere-se que o uso sustentável desta macrófita é possível em pequena escala.

Palavras-chave: distúrbio, bioindicação, manejo vegetal, macrófita aquática, produtos não-madeireiros 


\section{Introduction}

Wetlands are considered the most productive ecosystems in the world, mainly due to their high biodiversity (Tinner 1983). Therefore, wetlands are important areas for aquatic conservation being legally protected by environmental agencies. However, aquatic ecosystems have been severely affected by adverse circumstances (Santamaría \& Klassen 2002), more than half of wetland areas in the world disappeared during the last century as a consequence of urban and agricultural expansions (Shine \& Klem 1999). Thus, due to this not so optimistic background, it is necessary to develop environmental evaluation tools able to detect and measure human disturbances in these ecosystems, aiming their management and sustainable use.

Typha domingensis Pers is emergent and rhizomatous, being palustrine or aquatic. Their importance in wetland ecosystems is due to the large amount of organic matter produced by decomposition (Gonçalves Junior 2004, Santos \& Esteves 2006, Thomaz \& Cunha 2010). Macrophytes play an essential role in aquatic ecosystems, since they promote a spatial complexity linked to abundance, diversity and structure of macroinvertebrate communities (Dowing 1991, Thomaz et al. 2008, Thomaz et al. 2010, Mormull et al. 2011). Moreover, ecosystems dominated by aquatic macrophytes provide protection against macroinvertebrates predators, and food sources to grazers, detritivores and predators (Oertli \& Lachavanne 1995, Shaffer 1998).

Human activities are the main type of disturbance over wetlands integrity (e.g. artificial drought, fire, effluent discharge). Intensity, frequency, and extension of disturbances may influence the response of biological communities (Sousa 1984, Townsend et al. 1997, McCabe \& Gotteli 2000). Several works have aimed to evaluate the benthic macroinvertebrate responses to different kinds of disturbances in wetlands. These studies suggest a broad variation of responses (Szalay \& Resh 1997, Szalay \& Cassidy 2001, Martin \& Neely 2001, Kostecke et al. 2005, Schmidt et al. 2005, Rehage \& Trexler 2006, Silveira et al. 2011b). Benthic macroinvertebrates are a useful tool for environmental agencies (Rodrigues et al. 2006), providing consistent information related to multiple sources of disturbance and response (Rosenberg \& Resh 1992).

T. domingensis is present in dense stands, occurring in marshlands, lagoon banks, lakes, rivers and artificial channels; it is widespread throughout the Brazilian territory (Kissmann 1997). In some cases it is considered undesirable, once can be invasive with fast growth where conditions are favorable. Management of this species and other macrophyte species has been done via traditional practices in many parts of the world: small farmers harvest the stems for handicrafts fabrication, serving as an important income source (Coelho de Souza 2003, Silveira et al. 2011a).

Therefore, considering the importance of maintenance and conservation of wetlands and their biota, and the growing environmental threats that they have suffering, this work aims to go into the cut effect on benthic macroinvertebrates and evaluate macrophyte regeneration after cutting. We want to test the following hypothesis: (i) $T$. domingensis cutting affect the macroinvertebrate biota and (ii) the cutting affect the new shoots development and biomass production. In order to test our hypothesis we carried out a field experiment in which we conducted an experimental cuting of T. domingensis evaluating the macroinvertebrate response and the regeneration.

\section{Methods}

\section{Study area}

The experiment was carried out in a wetland area with approximately 1 ha, characterized by a dense stand of $T$. domingensis $\left(29^{\circ} 40^{\prime} 59,4^{\prime \prime} \mathrm{S}\right.$ and $\left.50^{\circ} 12^{\prime} 21,2^{\prime \prime} \mathrm{W}\right)$, on a private property nearby Maquiné town. The site consists of a swamp area belonging to the Maquiné River watershed, located on the northern coast of Rio Grande do Sul, in the southern portion of the Brazilian Pluvial Atlantic Forest (Figure 1). According to the classification system proposed by Malthick et al. (2004), the selected site is classified as a palustrine system with a water column presenting emergent vegetation. This site was chosen due to easy access to the experiment and logistical support. In addition, it is an area where local inhabitants harvest T. domingensis. The experiment was carried out in 2005, starting on June 21 and lasting 182 days.

\section{Experimental design}

Five areas with dimensions of $2.5 \mathrm{~m} \times 5 \mathrm{~m}$ were delimited inside the macrophyte stand in a transect of $50 \mathrm{~m}$ in length parallel to border, this approach were used to avoid environmental variations provided by border effect. Each delimited area was subdivided in to eight squares $\left(1 \mathrm{~m}^{2}\right)$, totalizing 40 squares delimited, 20 cut and 20 uncut. The experiment started after we performed the cutting on $T$. domingensis in four subdivisions at each five delimited areas distributed alternately. We randomly choose to sample one of the delimited area in the following time sequence after cutting: 1 day, 26 days, 60 days, 89 days, and 182 days.

\section{Macroinvertebrate sampling}

Macroinvertebrate were sampled with a corer $(0.5 \mathrm{~m}$ length; $10 \mathrm{~cm}$ diameter) at each treatment. The sampling was carried out by introducing the corer about $20 \mathrm{~cm}$ into the sediment at the center of each square. Once sampled, the sediment was conditioned in plastic bags and preserved in $95 \%$ ethanol. In the laboratory, the samples were stained with Rose Bengal during 24 hours and washed in a $250 \mu \mathrm{m}$ sieve; the retained macroinvertebrates were sorted out under stereomicroscope. The benthic macroinvertebrates were assigned to the family level according to the following identification keys: McCafferty (1981), Brinkhurst \& Marchese (1989), Pennak (1989), Trivinho-Strixino \& Strixino (1995) and Merrit \& Cummins (1996). Turbellaria and Collenbola were assigned to the class level. We assigned morphospecies and for the consistency in determination, we made a reference collection.

\section{T. domingensis regeneration}

The regeneration of $T$. domingensis was monitored in monthly sampling campaigns $(n=7)$ between July 30 and December 17, 2005. Eight squares $\left(1 \mathrm{~m}^{2}\right)$ were chosen among the five delimited areas, four cut areas and four control areas. All T. domingensis individuals were identified with numbered plastic tags in both treatments (cut and control areas). They were measured with a ribbon beginning at $20 \mathrm{~cm}$ from the rhizome upwards. Each new shoot was identified, measured and monitored as well. All stem were classified as shoot, mature, dead and with absence or presence of inflorescence. Shoots were characterized as $<80 \mathrm{~cm}$ high, mature $>80 \mathrm{~cm}$ high, and dead as predominantly yellow-brown color. During the experiment new shoots of $T$. domingensis $(<80 \mathrm{~cm})$ were monitored in order to assess the cut influence on their growth. To estimate the biomass of T. domingensis, 53 individuals of different sizes were measured in height and the dry mass obtained after all stems were dried at $60{ }^{\circ} \mathrm{C}$ during 120 hours and weighed in December 2005. The values were transformed into $\log (\mathrm{x}+1)$ and the biomass estimated by linear regression.

\section{Data analysis}

The macroinverbrates total density (individuals $/ \mathrm{m}^{2}$ ) were tested by means of Analysis of Variance (ANOVA), we considered $p<0.05$ 


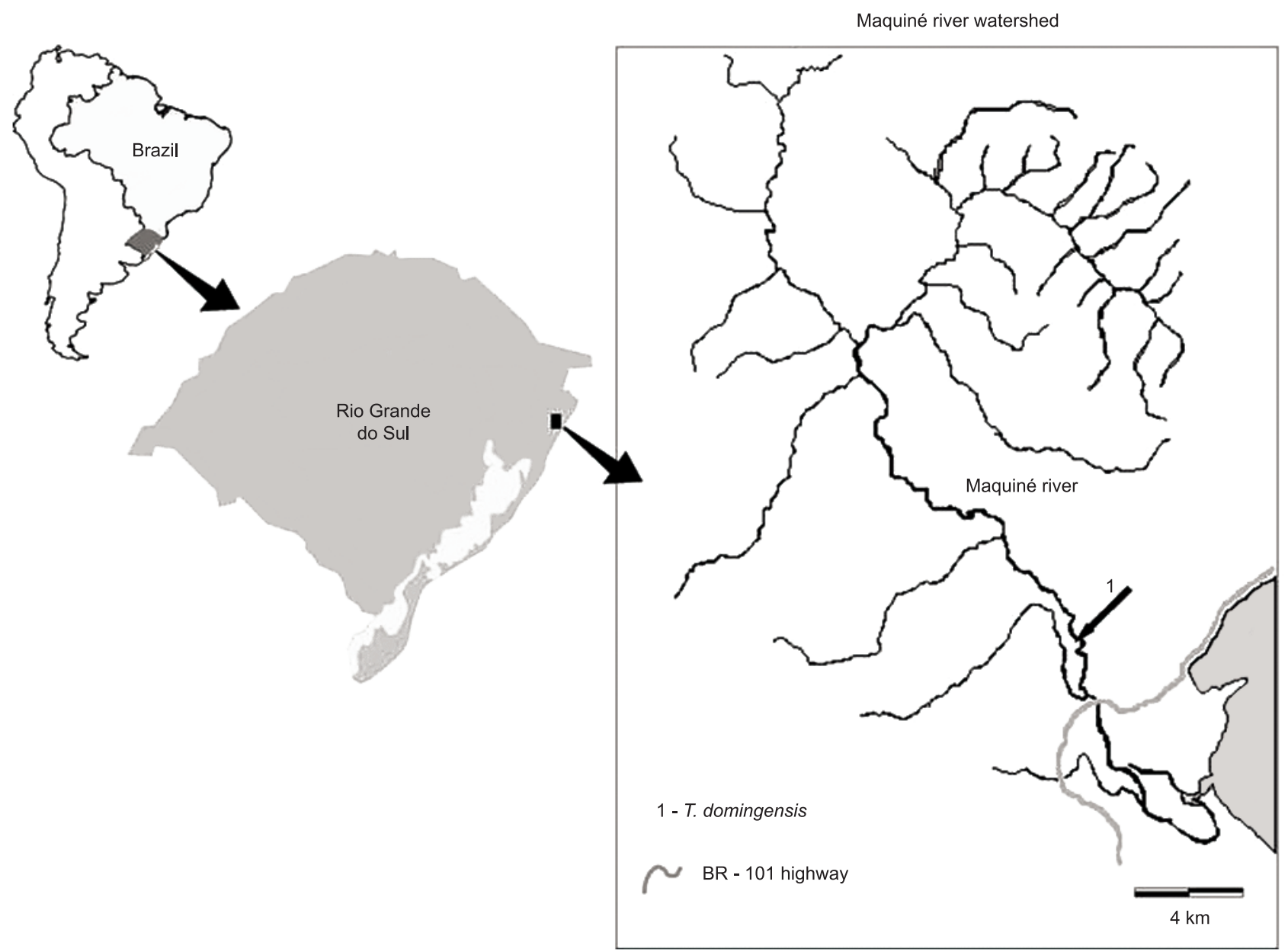

Figure 1. Study area at Maquiné. Rio Grande do Sul. Brazil. The arrow indicates the T. domingensis stand site.

statistically significant. Two factors were considered: sampling date and treatment. Only taxa with abundance $>4 \%$ were considered, we used this criteria of matrix reduction because rare species do not present analyzable patterns (Field et al. 1982, Szalay \& Resh 1997). The macroinvertebrate densities were $\log$ transformed $\log (\mathrm{x}+1)$ to reduce data variations. A t-test was used to test the cutting effect on shoot growth, biomass production and reproductive structures production.

We performed a DCA (Detrended Correspondence Analysis) ordination in order to segregate samples by time and treatment. To perform the DCA, all macroinvertebrate densities were within-sample percent transformed followed by a second trans-formation, a withintaxon percent maximum transformation (relativization by maximum of McCune \& Grace 2002; standardization to species maximum of Jongman et al. 1995) to equalize differences in abundance among taxa and prevent the ordination results from being dominated by the most abundant taxa. ANOVA, t-test, DCA and linear regression were performed with R software (The R Development Core Team 2012). DCA and data transformations were performed using DECORANA from the VEGAN package in R software.

\section{Results}

In this work, 1056 benthic macroinvertebrates belonging to 23 taxonomic groups were collected (Table 1). Ceratopogonidae
(36.3\%), Naididae (11.4\%), Tubificidae (11.7\%), Enchytraeidae (9\%), Sphaeridae (9.6\%), Chironomidae (4.7\%), Glossiphonidae (4.7\%) and Hirudinidae $(4.1 \%)$ were the dominant families that comprise $84.8 \%$ of the total macroinvertebrate sample. The macroinvertebrate densities are presented in Figure 2.

Only minimal differences among sampling dates were found with regard total density of macroinvertebrates (Figure 3). The ANOVA detected statistical differences total density of macroinvertebrates to the factor sampling date. This result allows inferring a temporal variability occurrence (Table 2 ). The interaction between period and treatment didn't show significant differences.

Although during the whole experiment Tubificidae showed significant statistical differences in relation to treatment (Table 2), it showed strong differences in relation to the densities in the treatments that were carried out every 26 days, 60 days, and 182 days. The remaining dominant taxa showed statistical differences in relation to the sampling date factor (Table 2). Significant differences were detected in regard to the sampling date factor of Naididae, which had an accentuated variation especially during the last sampling date (Figure 3a). Glossiphonidae also presented statistical differences regarding its sampling date factor. Sphaeridae presented statistical differences only to the sampling date factor, with elevated densities on the first day and on the $182^{\text {th }}$ day (Figure $3 \mathrm{f}$ ). Ceratopogonidae 


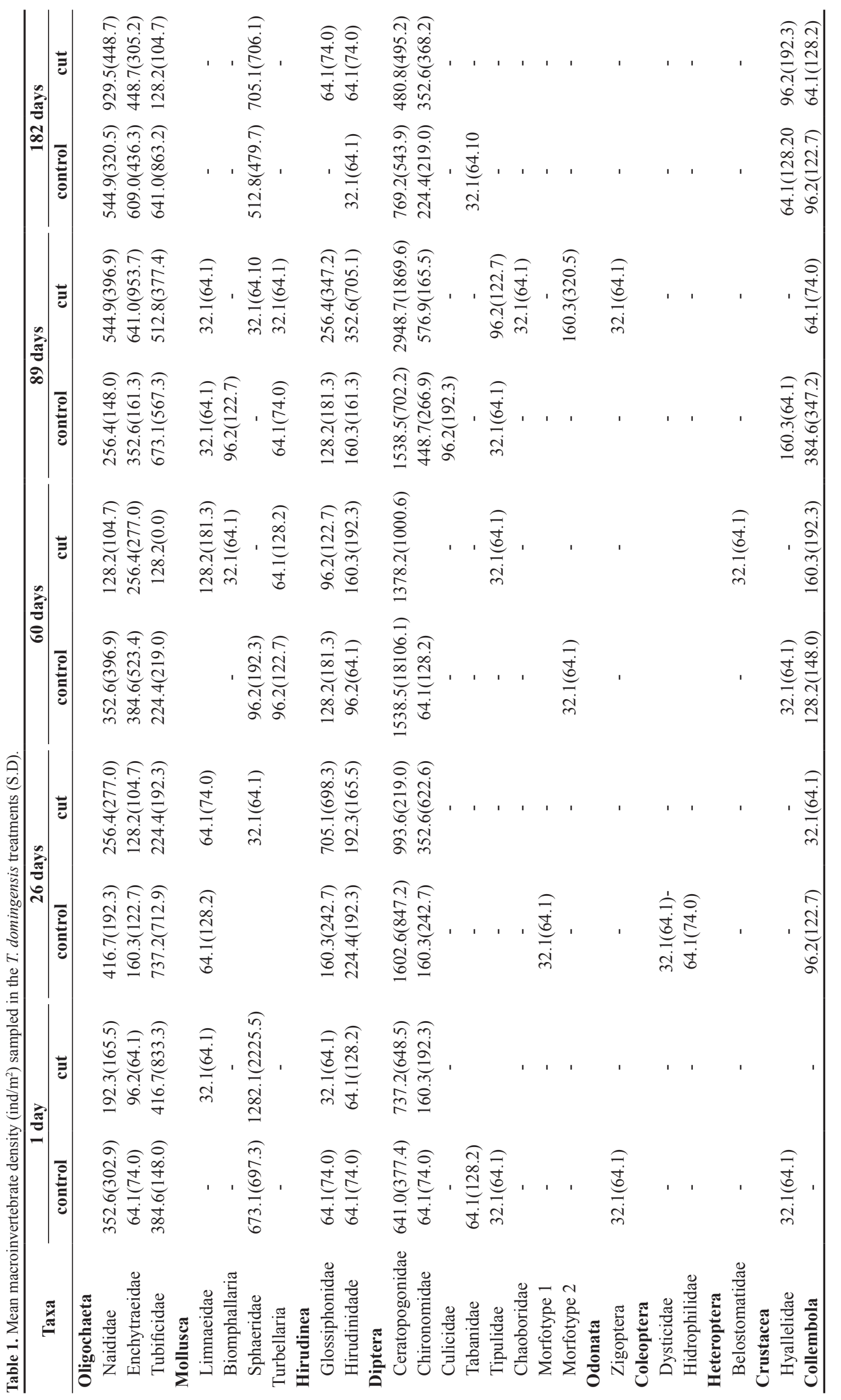


and Chironomidae showed slight differences between treatments and sampling dates after the disturbance (Table 2).

According to the DCA ordination plot (Figure 4), the first axis explained for $42 \%$ of variation and the axis 2 explains $30 \%$ of this amount. The ordination indicates a clear overlapping between treatments and sampling dates (Figure 4a) being not showed a clear group separation. In relation to taxa we observed a distribution not well defined, suggesting that the cut was not a strong enough disturbance to cause acute effects.

The density of intact $T$. domingensis stems prior to the experiment was $38 \pm 3.7$ stems $/ \mathrm{m}^{2}(\mathrm{n}=4)$. At the end of the experiment, 182 days after the cut event, the density was $28.0 \pm 2.3$ and $28.0 \pm 2.5$ stems $/ \mathrm{m}^{2}$ in controls and cut treatments, respectively. The growing of new shoots that were monitored during the experiment did not

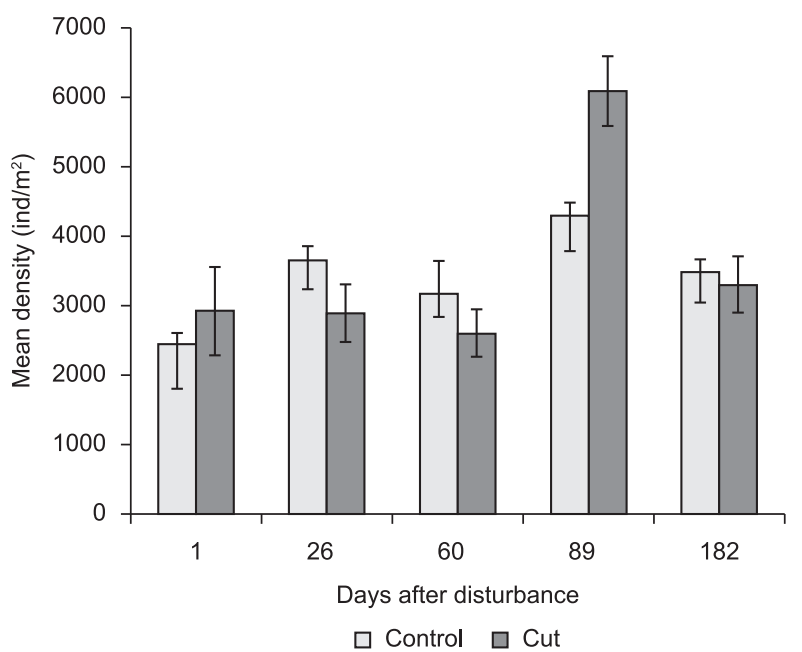

Figure 2. Mean density in disturbed and control treatment, black bars indicate the standard error. showed statistical differences between treatments and sampling dates ( $\mathrm{p} \geq 0.05)$ (Figure 5).

The model used to estimate the biomass was $\mathrm{y}=-0.3133508$ [-exp $(0.203461 \mathrm{x})]\left(\mathrm{r}^{2}=0.89\right)$. During the experiment, only sampling dates 1 and 26 after cut disturbances presented statistical differences $(p<0.05)$ between treatments; on the remaining sampling dates cutting treatment did not differ from control. However, biomass decrease in the treatments was observed in the period comprised between the $26^{\text {th }}$ day and the $60^{\text {th }}$ day after the cut disturbance (Figure 5). In regard to T. domingensis classification, statistic differences on the sampling date 1 after the cut disturbance were observed in relation to the number of adult stems (Table 3 ). Other $T$. domingensis classification did not present statistical differences at any sampling date.

\section{Discussion}

The environmental characteristics of $T$. domingensis, as analyzed in this study, are common in wetland areas and are similar to those found in the Paraná River watershed, according to Zozaya \& Neiff (1991). Low concentrations of dissolved oxygen are expected for these areas, due to its high consumption that is mediated by the decomposition process and accelerated by warm temperatures. Based on this background, it was assumed that in the present study a hypoxic macroinvertebrate assemblage would be found, such as oligochaets and dipterans. Besides, considering some characteristics of $T$. domingensis stand, such as a palustrine area with low water column oscillation (only a few centimeters), and also considering the sampling method, a low diversity of macroinvertebrates was noticed in the study area. Thus, our assumptions seem to be in agreement with those found by Kostecke et al. (2005) and Szalay \& Resh (1997).

Our first hypothesis is that the cut of $T$. domingensis affect the macroinvertebrate fauna were corroborated only to Tubificidae. Concerning the climatic factor, our experiment began in winter and finished in summer, and variations in the composition of macroinvertebrates taxa are expected for aquatic invertebrates

Table 2. ANOVA with macroinvertebrates density and dominant families sampled.

\begin{tabular}{|c|c|c|c|c|c|c|}
\hline \multirow{2}{*}{ Effect } & \multirow{2}{*}{ d.f. } & Macroinvertebrates density & Naididae & Enchytraeidae & Tubificidae & Ceratopogonidae \\
\hline & & $\mathbf{F}$ & $\mathbf{F}$ & $\mathbf{F}$ & $\mathbf{F}$ & $\mathbf{F}$ \\
\hline $\mathrm{S}$ & 4 & 2.19 & $2.53^{*}$ & 2.22 & 1.26 & $4.00^{*}$ \\
\hline $\mathrm{T}$ & 1 & 0.34 & 0.17 & 0.05 & $4.85^{*}$ & 0.06 \\
\hline $\mathrm{S} * \mathrm{~T}$ & 4 & 0.34 & 1.06 & 0.06 & 0.43 & 0.62 \\
\hline & & $\begin{array}{l}\text { Chironomidae } \\
\text { F }\end{array}$ & $\begin{array}{c}\text { Sphaeridae } \\
\text { F }\end{array}$ & $\begin{array}{c}\text { Glossiphonidae } \\
\text { F }\end{array}$ & $\begin{array}{c}\text { Hirudinidae } \\
F\end{array}$ & \\
\hline S & 4 & 6.42 & 7.07 & $2.39 *$ & 0.91 & \\
\hline $\mathrm{T}$ & 1 & 0.71 & 0.0009 & 1.78 & 0.54 & \\
\hline $\mathrm{S} * \mathrm{~T}$ & 4 & 0.81 & 0.17 & 0.93 & 0.36 & \\
\hline
\end{tabular}

$\mathrm{S}=$ sampling date; $\mathrm{T}=$ treatment; $\mathrm{S} * \mathrm{~T}=$ interaction between sampling date and treatment.* $=\mathrm{p}<0.05$.

Table 3. Mean number of $T$. domingensis stem classification demonstrated during the experiment (S.D).

\begin{tabular}{|c|c|c|c|c|c|c|c|c|}
\hline \multirow{2}{*}{ Sampling date } & \multicolumn{2}{|c|}{ Dead } & \multicolumn{2}{|c|}{ Shoots } & \multicolumn{2}{|c|}{ Adult } & \multicolumn{2}{|c|}{ Inflorescence } \\
\hline & control & cut & control & cut & control & cut & control & cut \\
\hline 1 & 0 & 0 & $1.7(2.2)$ & $3(1.7)$ & $43.7(3.6)$ & 0 & 0 & 0 \\
\hline 26 & $10(6.7)$ & $22(16.6)$ & $31(1.2)$ & $5(3.8)$ & $18.5(7.7)$ & $5(2.5)$ & 0 & 0 \\
\hline 60 & $8(7.2)$ & $25(15.7)$ & $1.5(1.8)$ & $2.7(5.3)$ & $16.2(5.6)$ & $17.5(2.1)$ & 0 & 0 \\
\hline 89 & $14(6.3)$ & $14.7(3.6)$ & $2.2(1.5)$ & $1(0.5)$ & $21.5(8.9)$ & $15.5(2.2)$ & $2.2(1.5)$ & 0 \\
\hline 118 & $5.5(0.57)$ & $3.2(1)$ & $0.5(0.57)$ & $1.7(0.9)$ & $22.5(6.9)$ & $23.2(1.6)$ & $0.2(0.5)$ & 0 \\
\hline 153 & $0.7(1)$ & $0.2(0.5)$ & $1.2(2.5)$ & $0.2(0.5)$ & $29.0(3.4)$ & $19.0(2.6)$ & $4.7(5.1)$ & $5.2(3.3)$ \\
\hline 182 & $0.2(0.5)$ & $0.2(0.5)$ & $0.7(2.4)$ & 1(2) & $25.7(3.3)$ & $23.2(3.5)$ & $8(3.1)$ & $7.2(5)$ \\
\hline
\end{tabular}



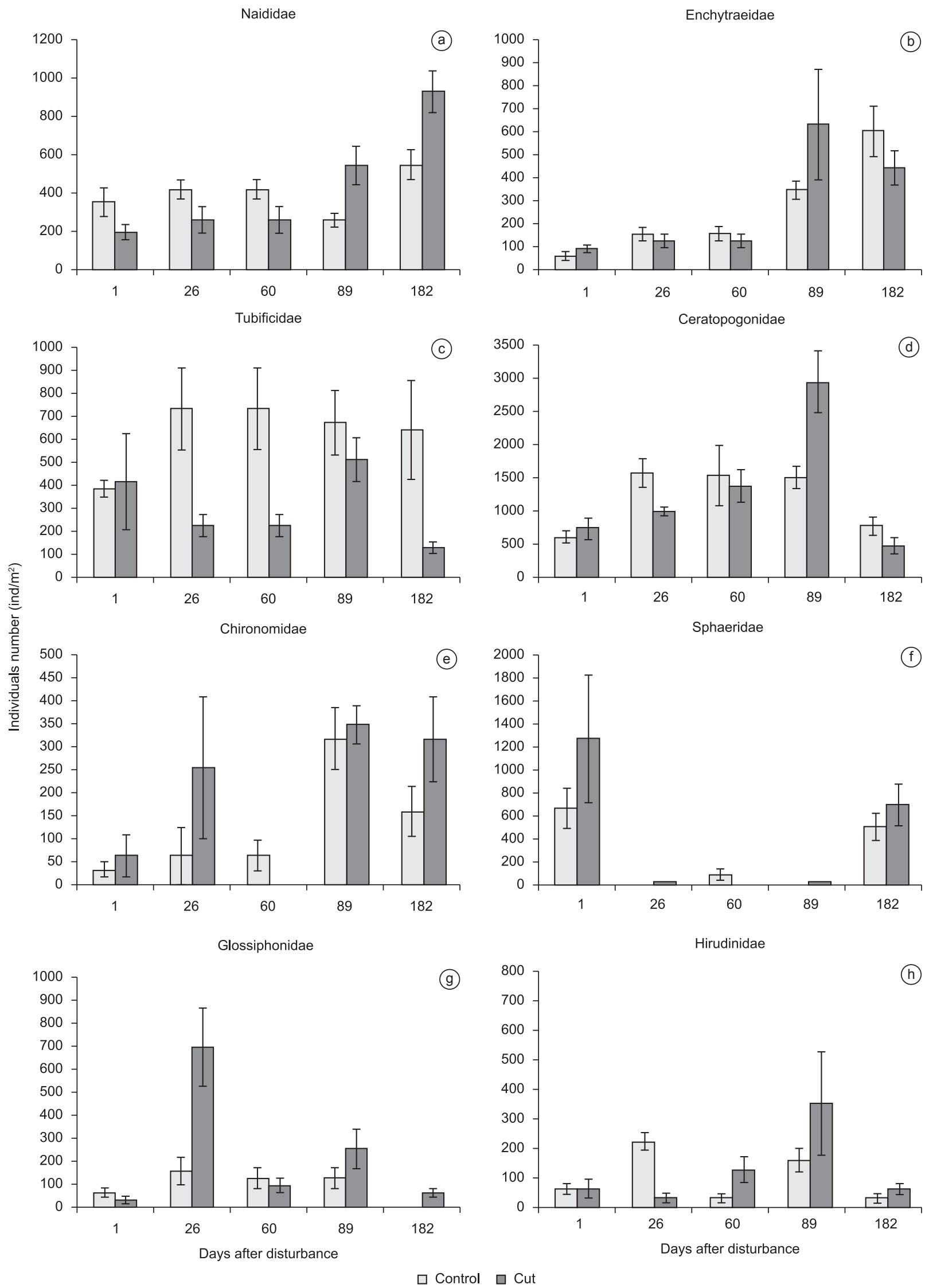

Figure 3. Mean density of dominant macroinvertebrates, black bars indicate the standard error. 

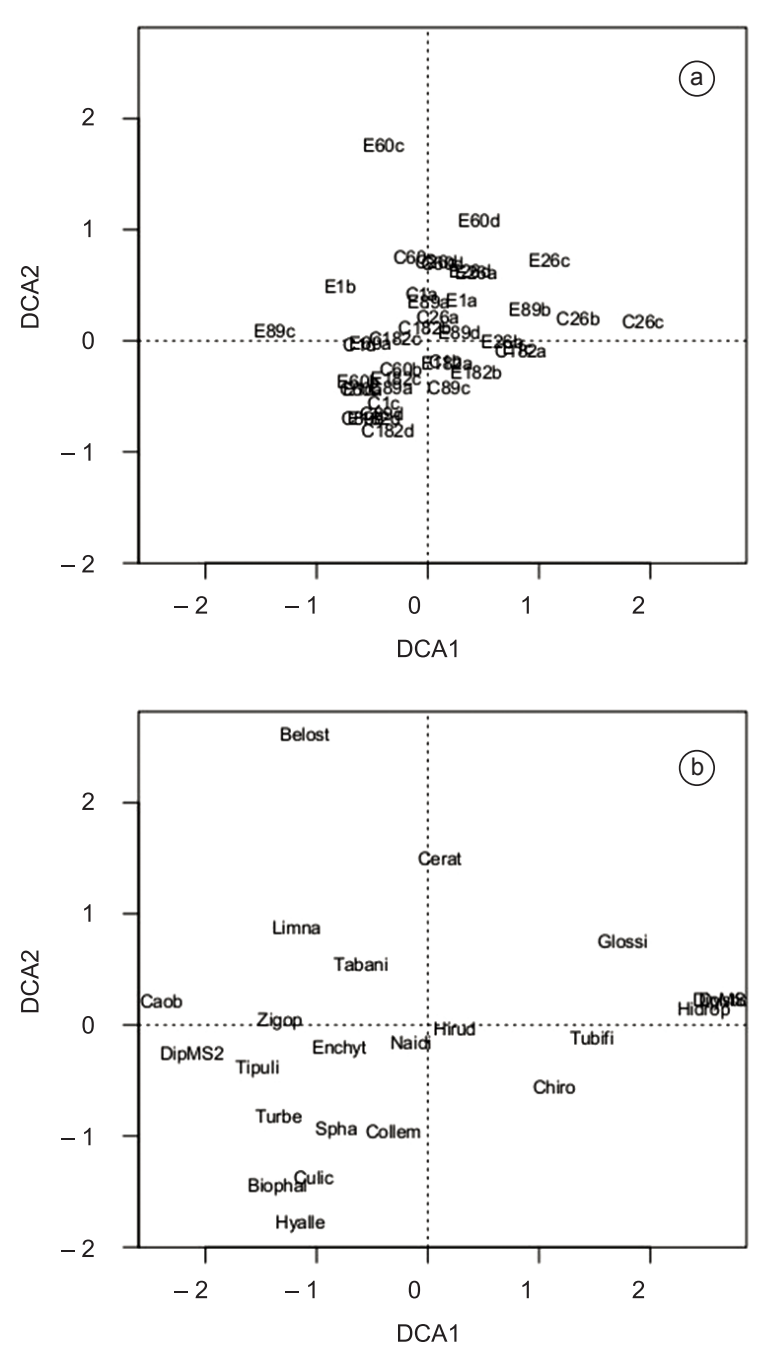

Figure 4. Detrended Components Analysis (DCA) of macroinvertebrate density. a) Sample plot ordination. c) Control, e) Cut, numbers indicates the days after disturbance event. b) Taxa plot ordination of taxa. Taxa names were abbreviated.

during this period. A variation in the composition of taxa, in relation to treatment and temporal factors, was detected most likely due the variations in periods of invertebrate's colonization and emergence of insects. Szalay \& Resh (2000) obtained similar results regarding the effects of these variations on macroinvertebrate assemblages. Furthermore, the macroinvertebrate response to the $T$. domingensis cut event, no significant statistical differences were verified in relation to the interaction between treatment and sampling date. The only observed variations are related to the taxonomic composition and to an expected temporal variation of density. The weak response of aquatic invertebrates to mechanical disturbances has been observed by Frid et al. (1997), who evaluated the response of aquatic invertebrates to light management in stands of Spartina anglica (Poaceae). Kostecke et al. (2005) also detected little difference in the response of aquatic invertebrates to mechanical management in Typha spp. However, Szalay \& Resh (1997) observed that areas colonized by Distichlis spicata (Poaceae) subjected to fire and cut disturbances tend to show elevated abundances of Chironomidae, Hemiptera and Oligochaeta. Also, Szalay \& Resh (1997), verified that the abundance of the latter (Oligochaeta) maybe be decreased as a response to the cut disturbance. Our results are in according with Szalay \& Resh
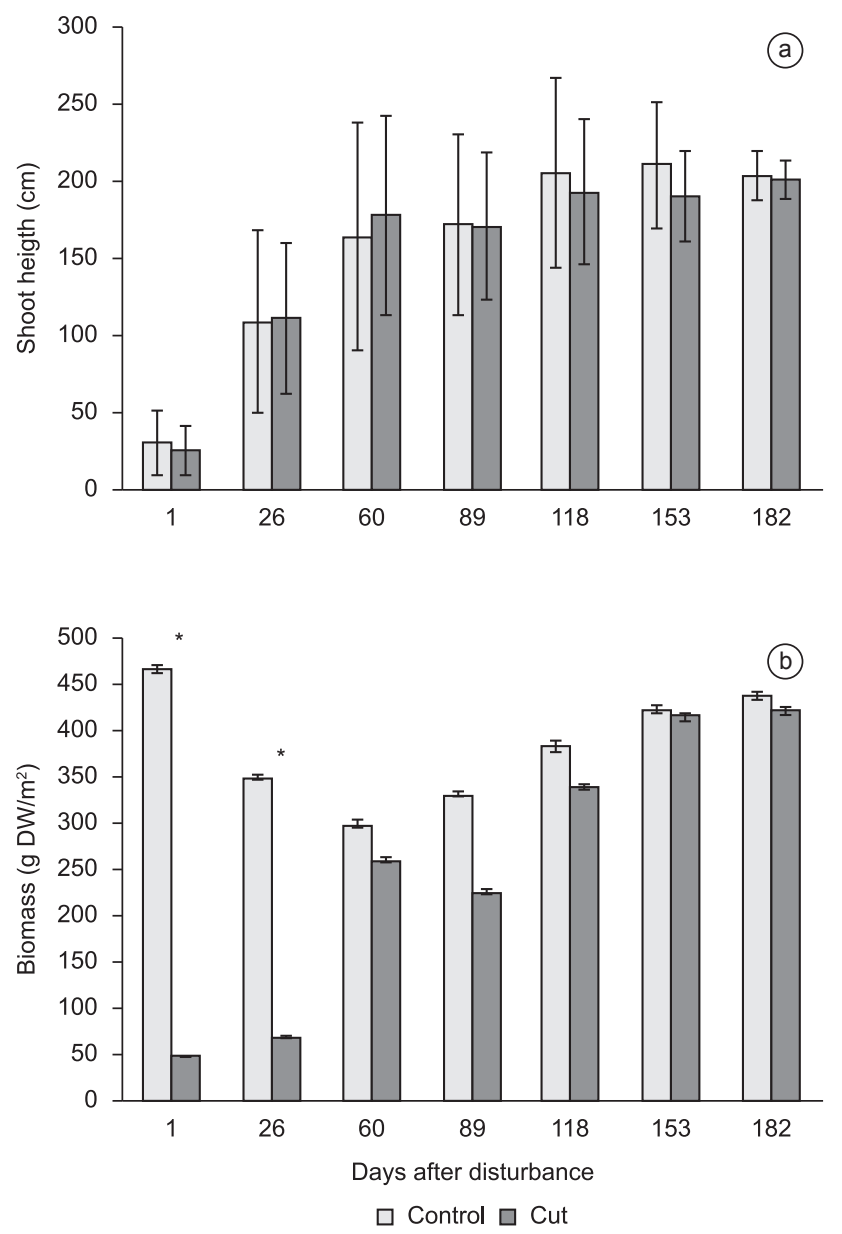

Figure 5. Stem growth (a) and regeneration of $T$. domingensis after cut (b). Black lines indicate the standard deviation. $*=p<0.05$.

(1997), suggesting that Tubificidae responded negatively to the cut disturbance in the treatment. In another study Frid et al. (1997) observed that Oligochaeta are subject to disturbances of low or intermediate strength.

Another important cause of the no response of majority of macroinvertebrate taxa could be determined by the size of the disturbed area, disturbance intensity and/or frequency. An adult fauna could easily reestablish in small areas with a reasonable dispersion in disturbed areas $<2000 \mathrm{~m}^{2}$ (Frid et al. 1999). In our study the frequency of disturbances in the delimited disturbed areas could be one of the reasons behind the weak response of aquatic macroinvertebrates; the disturbances may not have been sufficient to induce perceptible structural and functional changes. The intensity of the cut performed on $T$. domingensis could also be insufficient to induce perceptible changes in the macroinvertebrate assemblages. T. domingensis was cut only once and the sediment was not disturbed during sampling. A weak macroinvertebrate assemblage response to the disturbance could be linked to water column oscillation throughout the experimental area. The slight variation in water column depth may connect adjacent areas to the experimental location, making possible macroinvertebrate colonization or emigration. This were observed by Sousa (1984) inferring that might be the main factor behind macroinvertebrate assemblage resilience. Some studies utilize the isolation of disturbed vegetation areas with barriers of netting, to prevent the dispersion of invertebrates to other treatments and prevent possible colonization by species from adjacent areas (Szalay \& Resh 1997, Martin \& Neely 
2001). Since this specific technique was not used in our study, we suggest that colonization could indeed be one of the causes of high macroinvertebrate assemblage resilience in our experiment, because macroinvertebrate immigration after the disturbance could disguise direct effects of disturbance.

Concerning our second hypothesis that the cut affect T. domingensis development, we found that the quick resilience of macrophyte combined with other environmental factors could be an important force behind the macroinvertebrate resistance to the disturbance. $T$. domingensis have fast growth rates and is able to colonize a broad range of environment due to its striking clonal growth, ensuring for this species a high resilience capacity. A slight biomass variation was detected probably because this period was the coldest of the year. According to Palma-Silva et al. (2005) climatic and environmental factors could affect the mortality and productivity rates in T. domingensis stands.

The vegetative classifications observed during the experiment demonstrated a slight effect on the macrophyte, which regenerated 60 days after the disturbance. It should be emphasized that the number of inflorescences in both treatments did not show significant difference at the end of regeneration monitoring. The lack of differences between treatments in the number of inflorescences shows that the cut disturbance did not affected the gamethophyitic reproduction of $T$. domingensis. However, it's necessary to evaluate another structures of $T$. domingensis stands, because these ecosystems are subject to different environmental variables (e.g., geomorphology, water column oscillation and fetch), which could affect the macroinvertebrate response to cut disturbances and could show a broad range of responses.

\section{Conclusions}

The experimental cut disturbances did not caused alterations in macroinvertebrate density. Regarding the taxa evaluated we only found significative differences concerning the temporal variation (Figure 2 and 3). The scale intensity and frequency of cut areas utilized in this experiment was insufficient to induce an evident benthic macroinvertebrate response to a disturbance event. Regarding $T$. domingensis resilience, the macrophyte demonstrated quick regeneration and the cut had no effect on shoots growth and the gamethophytic production. Therefore we suggest that the use of this natural resource, in the evaluated area, could be sustainable with few prejudicial effects to the benthic macroinvertebrate and to the macronphyte as well.

\section{Acknowledgements}

The authors thank the colleagues from DESMA-UFRGS, ONG ANAMA, Benthic Invertebrates Laboratory - UFRGS and Romarize Klein. We also thank to Thais Paz Alves by english revision and Nelson Ferreira Fontoura by manuscript suggestions. We thank CNPq by the financial support and the scholarships provided by $\mathrm{CNPq}$ and CAPES.

\section{References}

BRINKHURST, R.O. \& MARCHESE, M.R. 1989. Guide to the freshwater aquatic Oligochaeta of South and Central America. Association Ciencias Naturales del Litoral, São Tomé.

COELHO DE SOUZA, G. 2003. Extrativismo em área de reserva da biosfera da Mata Atlântica no Rio Grande do Sul: um estudo etnobiológico em Maquiné. Tese de Doutorado, Universidade Federal do Rio Grande do Sul.
DOWING, J.A. 1991. The effect of habitat structure on the spatial distribution of freshwater invertebrate populations. In. Habitat structure: the physical arrangement of objects in space (S.S. Bell, E.D. McCoy \& H.R. Mushinsky, eds.). St. Edmundsbury Press, London, p.87-102.

FIELD, J. G., CLARKE, K. R. \& WARWICK, R. M., 1982. A practical strategy for analyzing multispecies distribuition patterns. Marine Ecology - Progress Series 8, p. 37-52.

FRID, C.L.J., CHANDRASEKARA, W.U. \& DAVEY, P. 1999. The restoration of mud flats invaded by common cord-grass (Spartina anglica CE Hubbard) using mechanical disturbance and its effects on the macrobenthic fauna. Aquat. Conserv. 9:47-61. http://dx.doi.org/10.1002/ (SICI) 1099-0755(199901/02)9:1\%3C47::AID-AQC326\%3E3.0.CO;2-T

GONÇALVES JUNIOR, J.F., SANTOS, A.M. \& ESTEVES, F.A. 2004. The influence of the chemical composition of Typha domingensis and Nynphaea ampla detritus on invertebrate colonization during decomposition in Brazilian coastal lagoon. Hydrobiologia 527:125-137. http://dx.doi.org/10.1023/B:HYDR.0000043190.49651.dc

JONGMAN, R.H.G., TER BRAAK, C.J.F. \& VAN TONGEREN, O.F.R. 1995. Data analysis in community and landscape ecology. 2nd ed. Cambridge Univ. Press, Cambridge.

KOSTECKE, R.M., SMITH, L.M. \& HANDS, H.M. 2005. Macroivertebrate response to cattail management at cheyenne bottons. Wetlands 25(3):758-763. http://dx.doi.org/10.1672/02775212(2005)025[0758:MRTCMA]2.0.CO;2

KISSMANN, K.G. 1997. Plantas Infestantes e Nocivas. BASF, São Paulo, p.802-807.

MALTHICK, L., ROLON, A.S., GARAGING, D.L. \& STERNEST, C. 2004. Wetlands of Rio Grande do Sul. Brazil: a classification with emphasis on plant communities. Acta Limnol. Bras. 16(2):137-151.

MARTIN, D.C. \& NEELY, R.K. 2001. Benthic macroinvertebrate response to sedimentation in a Typha angustifolia L. wetland. Wetl. Ecol. Manag. 9:441-454. http://dx.doi.org/10.1023/A:1012046624646

McCABE, D.J. \& GOTELLI, N.J. 2000. Effects of disturbance frequency, intensity, and area assemblages of streams macroinvertebrates. Oecologia 124:270-279. http://dx.doi.org/10.1007/s004420000369

McCAFFERTY, M. 1981. Aquatic Entomology. Boston. Science Books International.

McCUNE, B. \& GRACE, J.B. 2002. Analysis of Ecological Communities. MjM Software De-sign, Gleneden Beach, Oregon. 300p.

MERRIT, R.W. \& CUMMINS, K.W., eds. 1996. An introduction to the aquatic insects of North America. 3rd ed. Kendall, Hunt Publishing Co., Dubuque, Iowa.

MORMUL, R.P., THOMAZ, S.M., TAKEDA, A.M. \& BEHREND, R.D. 2011. Structural Complexity and Distance from Source Habitat Determine Invertebrate Abundance and Diversity. Biotropica 43(6):738-745. http:// dx.doi.org/10.1111/j.1744-7429.2011.00762.x

OERTLI, B. \& LACHAVANNE, J.B. 1995. The effects of shoot age on colonization of an emergent macrophyte (Typha latifolia) by macroinvertebrates. Freshwater Biol. 34:421-43. http://dx.doi. org/10.1111/j.1365-2427.1995.tb00900.x

PALMA-SILVA, C., ALBERTONI F.A. \& ESTEVES, F.A. 2005. Clonal Growth of Typha domingensis Pers. subject to drawdonws and iterference of Eleocharis mutata (L.) Roem. et Shult. in a tropical coastal lagoon. Wetl. Ecol. Manag.13:191-198. http://dx.doi.org/10.1007/s11273-0040268-6

R DEVELOPMENT CORE TEAM. 2012. R: A language and environment for statistical computing. R Foundation for Statistical Computing, Vienna. Austria. http://www.R-project.org (ultimo acesso em 20/07/2012).

RODRIGUES, G.G., SILVEIRA, T.C.L. \& BARBOSA, A.F. 2006. Macroinvertebrados Aquáticos e o Licenciamento Ambiental. Bol. Soc. Bras. Limnol. 35(2):47-51.

REHAGE, J.S. \& TREXLER, J.C. 2006. Assessing the net effect of anthropogenic disturbance on aquatic communities in wetlands: community structure relative to distance from canals. Hydrobiologia 569(1):359-373. http://dx.doi.org/10.1007/s10750-006-0142-z 
ROSENBERG, D.M. \& RESH, V.H. 1992. Introduction to Freshwater Biomonitoring and Benthic Macroinvertebrates. In Freshwater Biomonitoring and Benthic Macroinvertebrates (D.M. Rosenberg \& V.H. Resh, eds). Chapman and Hall, New York, p.1-10.

SANTAMARÍA, L. \& KLAASSEN, M. 2002. Waterbird-mediated dispersal of aquatic organisms: an introduction. Acta Oecol. 23 (3):115-119. http:// dx.doi.org/10.1016/S1146-609X(02)01144-X

SANTOS, A.M. \& ESTEVES, F.A. 2006. Primary production and mortality of Eleocharis interstincta in response to water level fluctuations. Aquat. Bot. 74(3):189-199. http://dx.doi.org/10.1016/S0304-3770(02)00082-7

SOUSA, W.P. 1984. Intertidal mosaics: patch size, propagule availability. and spatially patterns of succession. Ecology 65(6):1918-1935. http:// dx.doi.org/10.2307/1937789

SHAFFER, M. 1998. Ecology of Shallow lakes. Chapman and Hall, London.

SCHMIDT, M.H., LEFEBVRE, G., POILIN, B. \& TSCHARNTKE, T. 2005. Reed cutting affects arthropod communities potentially reducing food for passerine birds. Biol. Conserv. 121:157-166. http://dx.doi.org/10.1016/j. biocon.2004.03.032

SHINE, C. \& KLEMN, C. 1999. Wetlands. water and the law. Using law to advance wetland conservation and wise use. Ramsar Convention Bureau. Gland, Switzerland.

SILVEIRA, T.C.L., BASSI, J., RAMOS, C., TERME, C.M., FUHR, G., KUBO, R., RODRIGUES, G.G. MELLO, R.S.P., COELHO-DE-SOUSA, G. \& IRGANG, B.E. 2011a. Schoenoplectus californicus - Junco. In Espécies nativas da flora brasileira de valor econômico atual ou potencial: plantas para o futuro - Região Sul (L. Coradin, A. Siminski \& A. Reis, orgs.). MDA, Brasília, v.40, p.282-290.

SILVEIRA, T.C.L., RODRIGUES, G.G., SOUZA, G.P.C. \& WÜRDIG, N.L. 2011b. Effects of cutting disturbance in Schoenoplectus californicus (C.A. Mey.) Soják on the benthic macroinvertebrates. Acta Sci., Biol. Sci. 33(1):31-39.
SZALAY, F.A. \& RESH, V. 1997. Responses of wetland invertebrates and plants in waterfowl diets to burning and mowing of emergent vegetation. Wetlands 17(1):149-156. http://dx.doi.org/10.1007/BF03160726

SZALAY, F.A. \& RESH, V. 2000. Factors influencing macroinvertebrate colonization of seasonal wetlands: responses to emergent plant cover. Freshwater Biol. 45(3):295-308. http://dx.doi.org/10.1111/j.13652427.2000.00623.x

SZALAY, F.A. \& CASSIDY, W. 2001. Effects of Muskrat (Ondatra zibethicus) Lodge Construction on Invertebrate Communities in a Great Lakes Coastal Wetland. Am. Midl. Nat. 146:300-310. http://dx.doi.org/10.1674/00030031(2001)146[0300:EOMOZL]2.0.CO;2

THOMAZ, S.M. \& CUNHA, E.R. 2010. The role of macrophytes in habitat structuring in aquatic ecosystems: methods of measurement, causes and consequences on animal assemblages' composition and biodiversity. Acta Limnol. Bras. 22(2):218-236.

THOMAZ, S.M., DIBBLE, E., EVANGELISTA, L., HIGUTI, J. \& BINI, L.M. 2008. Influence of aquatic macrophyte habitat complexity on invertebrate abundance and richness in tropical lagoons. Freshwater Biol. 53:358-367

TINNER, R.W. 1983. Wetland indicators. Lewis, New York.

TOWNSEND, C.R., SCARSBROOK, M.R. \& DOLEDEC, S. 1997. The intermediate disturbance hypothesis, refugia and biodiversity in streams. Limnol. Oceanogr. 42(5):938-949. http://dx.doi.org/10.4319/ 10.1997.42.5.0938

TRIVINHO STRIXINO, S. \& STRIXINO, G. 1995. Larvas de Chironomidae (Diptera) dos estado de São Paulo. Guia de identificação e diagnose dos gêneros. PPG-ERN/UFSCAR, São Carlos.

ZOZAYA, I.Y.B. \& NEIFF, J.J. 1991. Decomposition and colonization by macroinvertebrates of Typha latifolia $\mathrm{L}$. litter in chaco cattail swamp (Argentina). Aqua. Bot. 40(2):185-193. http://dx.doi.org/10.1016/03043770(91)90096-N 